\title{
Human Suffering and Theological Construction of Suffering
}

\author{
Sonny Eli Zaluchu \\ Sekolah Tinggi Teologi Baptis Indonesia (STBI) Semarang \\ Email: sonnyzaluchu@stbi.ac.id
}

\begin{abstract}
Suffering, as a natural part of life, will be burdensome and burdensome when we respond in the wrong way. Therefore, it is necessary to have a theological construction so that humans can survive and pass through their sufferings victoriously. This paper aims to build a theological response to human suffering by proposing the presence of a theology of suffering. It can be concluded that through the theology of suffering, suffering humans can accept suffering as God's sovereignty. This theology also builds on the understanding that the way of suffering can identify God. The suffering experienced by humans does not come immediately because it has a unique purpose for everyone. It is also found that in the theology of suffering, God suffered through the death of His Son on the Cross for the benefit of humanity. This paper is written entirely with an analytic approach by relying on various theories and interpretations of Bible verses through in-depth literature studies
\end{abstract}

Keywords: theology, suffering, hope, pandemic, the Cross of Christ.

\begin{abstract}
ABSTRAK: Penderitaan sebagai bagian alami kehidupan, akan menjadi sesesuatu yang membebani dan menjerumuskan ketika ditanggapi dengan cara yang salah. Oleh sebab itu, diperlukan kehadiran sebuah konstuksi teologis agar manusia dapat bertahan dan melewati penderitaanya dengan kemenangan. Paper ini bertujuan untuk membangun tanggap teologis terhadap penderitaan manusia dengan mengusulkan kehadiran teologi penderitaan. Disimpulkan bahwa melalui teologi penderitaan, manusia yang menderita dapat menerima penderitaan sebagai sebuah kedaulatan Tuhan. Teologi ini juga membangun pengertian bahwa Allah dapat dikenali melalui jalan penderitaan. Penderitaan yang dialami manusia tidak hadir serta merta karena memiliki tujuan khas bagi setiap orang. Juga ditemukan bahwa di dalam sebuah teologi penderitaan, Allah ikut menderita melalui kematian anak-Nya di atas Salib untuk kepentingan manusia. Paper ini sepenuhnya ditulis dengan pendekatan analitik dengan mengandalkan berbagai teori dan tafsiran ayat-ayat Alkitab melalui pendalaman kajian pustaka.
\end{abstract}

Kata Kunci: teologi, penderitaan, harapan, pandemi, salib Kristus.

Article History: Submitted: 11 Februari 2021

\section{PENDAHULUAN}

Pandemi yang tidak kunjung berakhir telah merubah arah kehidupan manusia secara keseluruhan. Ekonomi dan politik terguncang di dalam sebuah krisis global yang akut. Humanisme dan kehidupan sosial mengalami krisis serupa. Kehidupan sosial tidak pernah sama dengan kondisi sebelumnya. Orangorang menjaga jarak dalam beraktifitas, membatasi pergaulan dan hidup di dalam bayang-bayang paparan virus yang tidak seorangpun dapat menebaknya ada di mana. Kematian terjadi di mana-mana dan tragedi menjadi bagian permisif dimana umat manu- sia tidak memiliki pilihan lain kecuali menerimanya. Ditinjau dalam perspektif manapun, umat manusia sedang mengalami penderitaan. Seluruh penduduk bumi seperti berjalan di dalam lorong panjang yang gelap, bertahan untuk hidup, dan berharap melihat setitik cahaya di ujung lorong yang tidak kunjung muncul (Wang, 2021). Muncul pertanyaan, apakah saat ini manusia sedang berada di dalam sebuah tragedi kehidupan yang tidak terpecahkan?

Dalam situasi seperti ini, pemikiran Fromm dapat dipergunakan sebagai pijakan awal, bahwa pandemi telah menempatkan umat manusia di dalam se- 
buah horizon baru perubahan sosial. Ideologi, sistem dunia, mahzab, bahkan teknologi terbukti telah gagal menyelesaikan persoalan ini. Menurutnya, hanya pengharapanlah yang mampu membuat umat manusia bertahan karena harapan merupakan elemen intrinsik struktur kehidupan yang terkait erat dengan dinamika roh manusia. Bahkan dengan sangat jelas Fromm (2019) menyimpulkan bahwa ketika manusia kehilangan harapan maka pada saat yang sama kehidupannya akan berakhir. Dengan kata lain, harapanlah yang membuat manusia mampu bertahan di dalam lorong gelap penderitaan. Harapan jugalah yang membuat manusia tetap percaya akan melihat cahaya di ujung lorong yang gelap tersebut.

Harapan memiliki kaitan yang sangat korelatif dengan iman. Fromm selanjutnya mengatakan bahwa iman tidak dapat bertahan tanpa ditopang oleh pengharapan. Demikian sebaliknya, harapan tidak memiliki dasar yang lain kecuali iman (Fromm, 2019). Hal ini sejalan dengan pemikiran Paulus di dalam Ibrani 6:19 yang mengatakan, "Pengharapan itu adalah sauh yang kuat dan aman bagi jiwa kita, yang telah dilabuhkan sampai ke belakang tabir." Berpijak pada literatur rabinik, Keener menafsirkan bahwa pengharapan seperti sauh yang mengamankan kapal dari goncangan badai dan arus laut, sehingga tetap berada di tempatnya dengan aman. Dasar laut tempat sauh itu mendarat adalah 'belakang tabir' yang adalah ruang Maha Kudus dalam terminologi Perjanjian Lama (Keener, 2014). Dengan kata lain, Tuhan sendirilah yang menjadi kekuatan bahkan sumber pengharapan yang dimaksudkan oleh Fromm tersebut.

Melibatkan Tuhan di dalam cara manusia mengaktualitasi dirinya menghadapi penderitaan, pada dasarnya selalu mengarah pada sebuah konstruksi teologis. Merujuk pada pengertian 'theology' sebagai sebuah wacana tentang Tuhan (McKim, 2014), terlihat bahwa penderitaan merupakan salah satu jalan memahami Tuhan di dalam konteks iman. Bandingkan dengan definisi awal teologi menurut Anselm dari Canterbury (1033-1109) yang mengatakan Teologi adalah sebuah credo ut intelligam (Faith seeking understanding). Ini adalah ungkapan Latin yang berarti "iman yang mencari pemahaman." Dimulai dengan asumsi bahwa "kita" adalah orang percaya dan, dengan demikian, terus berusaha untuk memahami keyakinan dengan lebih baik (Sparshott, 2017). Melalui persepektif ini, kehadiran pandemi yang membuahkan penderitaan, hanya dapat dihadapi ketika manusia menempatkan pengharapannya di dalam sebuah konstruksi teologis. Dengan cara seperti ini manusia dapat melihat penderitaan dalam perspektif Tuhan, sehingga tidak melulu melihat penderitaan sebagai sebuah masalah berat yang menghasilkan kesedihan, tetapi menempatkannya sebagai bagian atau proses yang harus dihadapi dari Tuhan.

Oleh sebab itu, membangun sebuah teologi yang bertema penderitaan menjadi sebuah solusi terpenting di tengah penderitaan akibat pandemi saat ini atau oleh sebab-sebab lain di dalam kehidupan ini. Hanya dengan cara seperti ini manusia akan keluar dari jebakan bertanya-tanya yang menghasilkan banyak pertanyaan semisal, Dimanakah Allah saat penderitaan terjadi? Mengapa penderitaan terjadi? Apakah Allah marah? Mengapa pertolongan-Nya seperti tersembunyi? Pertanyaan-pertanyaan tersebut di dalam konstruksi teologi penderitaan tidak membutuhkan jawaban ketika manusia akhirnya memahami bahwa Allah hadir di tengah-tengah manusia yang menderita.

Sejumlah riset pendahuluan mengenai topik ini telah dilakukan. Penelitian Robert et al. (2020) misalnya mengangkat masalah penderitaan dalam framing dilema etik. Bahkan penelitian Ahuja et al. (2020) mengangkat dan mengaitkan topik ini dengan Artificial Intelligence. Laporan penelitian yang disampaikan oleh Jamal et al. (2020) melakukan pengakajian pandemi dalam kaitannya dengan tourisme.

Riset-riset lain yang dilaporkan mayoritas berkaitan dengan domain kesehatan. Radbruch et al. (2020) menyebutkan istilah tsunami penderitaan tetapi hanya fokus pada masalah perawatan. Seperti halnya penelitian Cipriani dan Fiorino (2020) yang mengangkat masalah penderi-taan akibat pandemi 
khusus bagi penderita penyakit demensia. Yang berkaitan dengan kehidupan religi, spiritualitas dilakukan oleh Lucchetti et al. (2020) tetapi arah penelitiannya difokuskan pada kesehatan mental selama isolasi akibat pandemi. Seluruh pene-litian tersebut di atas ternyata belum menyentuh konsepsi penderitaan yang secara khusus dibingkai dalam kerangka teologis.

Paper ini mencoba mengisi kekosongan penelitian di dalam ranah teologis yang secara khusus mengangkat tema penderitaan dalam kaitannya dengan peta jalan menuju konstruksi teologi penderitaan di tengah pandemi dan sebab-sebab lain di dalam kehidupan. Sebagaimana Ayub katakan, Dia Tuhan yang memberi luka tetapi juga membebat (Ayub 5:18).

Paper ini mengetengahkan bahwa penderitaan adalah bagian alami dari kehidupan dan sebuah teologi penderitaan diperlukan untuk membangun pengertian bahwa Tuhan tidak pernah meninggalkan manusia. Melalui teologi penderitaan diharapkan terbentuk wawasan teologis sehingga setiap orang yang menderita memiliki pengertian yang benar yang memampukannya untuk bertahan dan tetap tegar.

\section{METODE}

Untuk mendiskusikan topik penelitian, paper ini akan membahas tiga topik utama. Pertama-tama menggagas ide dari sejumlah teolog yang pernah memperbincangkan tema penderitaan di dalam berbagai konteks. Hal ini diperlukan untuk membentuk alur berpikir di dalam menemukan poin-poin kunci penderitaan manusia dan kaitannya dengan penderitaan Allah. Kemudian pembahasan di arahkan pada rumusan konstruksi teologi penderitaan. Dalam hal ini pembahasan dimulai dari hal-hal normatif hingga pada konsep-konsep praktis yang diperlukan manusia untuk membaca penderitaan. Diskusi dan pembahasan disajikan dengan pendekatan integratif beberapa metode seperti pendekatan tafsir, critical analysis dan deskriptif naratif sebagaimana disebutkan oleh buku Missiological Research yang disunting oleh Gilbert et al. (2018).

\section{HASIL DAN PEMBAHASAN}

Teologi Penderitaan adalah sebuah rancang bangun teologi yang di buat manusia untuk memahami penderitaan. Di dalam teologi ini, manusia dibawa melampauhi horizon pemahaman bahwa dirinya merupakan objek rencana Allah yang tidak punya pilihan menghadapi kedaulatan-Nya. Konsepsi teologi ini juga menghadirkan pengertian paralel bahwa di dalam penderitaan manusia, Allah ikut bersolidaritas dan merasakan penderitaan itu (Zaluchu, 2017). Bahkan sejatinya, Dia adalah Allah yang juga mengalami penderitaan. Tidak ada pembicaraan mengenai penderitaan manusia tanpa melibatkan perbincangan mengenai penderitaan Allah. Karena dosa manusia maka Allah menderita di dalam kasih-Nya yang diwujudkan melalui kehadiran dan penderitaan Kris-tus (Wicaksono \& Anggono, 2019). Sebaliknya, karena berdosa, maka manusia mengalami penderitaan. Berdasarkan hal ini, sebuah teologi penderitaan menjadi $h u b$ dan bingkai yang mendasari pemahaman manusia mengenai makna penderitaan, sebab muasalnya dan tujuan kehadirannya. Dalam artikelnya berjudul "Teologi Bencana" Yewangoe (2005) mengusulkan penderitaan haruslah mendorong manusia untuk mengkonstruksikan suatu bangun teologi tentang penderitaan itu sendiri sehingga membangun nilai-nilai internal di dalam dirinya yang lebih permisif tentang penderitaan itu dalam sebuah 'Grand Desain Allah'. Melaluinya manusia menjadi lebih tawakal, sabar dan tidak terjebak pada kepanikan-kepanikan yang membuatnya gagal melanjutkan hidup. Melalui teologi tersebut, setidaknya manusia dapat menjadi manusia dan menyadari bahwa Allah ikut menderita bersamanya. Hal yang disampaikan Yewangoe tersebut mengarah pada aspek manusiawi manusia sebagai ciptaan yang memang tidak dapat dilepaskan dari penderitaan.

\section{Tanggapan Teolog}

Harus diakui perbincangan tentang penderitaan dalam relasi Allah dengan manusia adalah sebuah misteri. Tetap tidak akan pernah ada kepuasan 
untuk menjawab pertanyaan-pertanyaan mendasar, mengapa timbul penderitaan, dimanakah Allah dalam penderitaan manusia, apakah penderitaan itu seijin Allah? Bukankah Allah itu maka kasih? Analisis tentang penderitaan Ayub misalnya, adalah sebuah misteri besar bagi manusia di dalam membangun kerangka teologinya (Kurniadi, 2015). Mengapa Allah misalnya, punya hati yang tega menjerumuskan Ayub ke dalam malapetaka besar, hanya karena "bertaruh" mengenai pendirian iman Ayub kepada Iblis? Bukankah ini sebuah kekonyolan melihat manusia fana yang dengan bebas diperlakukan Allah dalam sebuah pertarungannya supranatural dengan Iblis? Demikian juga pertanyaan mengenai apakah Allah ikut menderita bersama manusia? Pada bagian mana saja dikatakan Allah menderita? Mengapa Allah dikatakan menderita? Apakah Allah yang menderita itu membawa manusia ikut menderita bersama-Nya?

Sejumlah pertanyaan tersebut menjadi bahan kajian dari para teolog dari masa ke masa untuk mencari jawabannya dan menyusun satu perspektif baru berteologi, sehingga di dalam penderitaan yang dialaminya, manusia dapat bertahan dan melanjutkan kehidupannya dengan tetap bergantung kepada Allah dan ikut merasakan bagaimana Allah menderita di dalam Grand Design-Nya (Weinandy, 2003). Memahami penderitaan Allah akan membangkitkan keyakinan iman bagi manusia untuk memahami penderitaannya sendiri.

Moltmann dalam karyanya The Crucified God mengatakan bahwa kuasa dan kemuliaan bukanlah jalan yang dipilih Allah untuk menyatakan diri kepada manusia, melainkan melalui jalan penderitaan yang berpuncak pada salib (Migliore, 1975; Jür. Moltmann, 1974; Mostert, 2013; Zaluchu, 2017). Seruan kematian Kristus di atas salib, "Allah-Ku, Allah-Ku, mengapa Engkau meninggalkan Aku?" bagi Moltmann adalah sebuah gagasan teologi yang berpusat pada Kristus, yang dibangun melalui pengalaman-Nya di atas Salib. Dari sana manusia dapat melihat siapa Allah yang sesungguhnya. Salib menjelaskan dua karya Allah yang penting, bertindak untuk kepentingan manusia dan bertindak untuk kepentingan diri-Nya sendiri, yang dengan sengaja memilih jalan tersebut untuk memperlihatkan rencana dan kedaulatan-Nya. Salib memperlihatkan bahwa Allah ikut menderita karena telah mengorbankan anak satusatunya demi manusia. Hal tersebut dilakukan karena kasih-Nya yang sangat besar. Penulis Injil Yohanes menegaskan hal tersebut. "Karena begitu besar kasih Allah akan dunia ini, sehingga Ia telah mengaruniakan Anak-Nya yang tunggal, supaya setiap orang yang percaya kepada-Nya tidak binasa, melainkan beroleh hidup yang kekal" (Yoh. 3:16). Dengan demikian terlihat bahwa kasih Allah menjadi salah satu sisi yang harus dilihat manusia di balik penderitaan.

Ekspresi kemanusiaan Yesus di dalam mengungkap penderitaan-Nya di atas salib karena merasa ditinggalkan oleh Bapa-Nya telah mewakili seruan hati manusia di dalam setiap penderitaan yang dialami. Sebagaimana manusia, Yesus merasa sendirian menanggung semua hal tersebut. Padahal, sejatinya Sang Bapa selalu dan ada di sana mendampingi anakNya, sebagaimana Ia juga melakukan hal serupa bagi setiap manusia yang menderita. Oleh sebab itu, tujuan refleksinya sangat jelas. Tidak ada alasan bagi manusia untuk merasa ditinggalkan Tuhan di dalam penderitaan yang sedang dialami (Stevanus, 2019). Allah ikut menderita di dalam dan bersama manusia. Dalam bukunya tesebut, Moltmann menegaskan bahwa salib adalah pusat identitas dan relevansi iman Kristen. Karena salib dan Kristus, seluruh persepsi manusia tentang Allah serta manusia harus ditafsirkan kembali (Boonyakiat, 2008). Moltmann juga mengatakan bahwa Allah sebagai penderita juga bersama-sama menderita dengan manusia. Penyebab kesengsaraan dan penderitaan yang manusia alami adalah kesengsaraan dan penderitaan Tuhan. Sejarah penderitaan manusia diambil dari sejarah penderitaan-Nya (J. Moltmann, 1975; Zaluchu, 2017). Hal ini berarti, penderitaan manusia adalah penderitaan-Nya.

Martin Luther, sang teolog reformasi, memiliki pandangan yang kurang lebih sama dengan Moltmann. Dalam rumusan teologinya yang terkenal, 
Theologia Crucis (Theology of the Cross), Luther memperkenalkan dialektika antara opus alienum Dei (karya Allah yang bertentangan) dan opus proprium Dei (karya Allah yang sebenarnya). Opus alienum Dei mengacu pada "memberantas, membunuh, mengambil harapan dan memimpin pada keputusasaan" dan opus proprium Dei mengacu pada "mengampuni, berbelas kasihan, menguatkan dan menyelamatkan". Kedua karya ini dihasilkan dari Allah kasih yang sama, dan opus propriumm Dei diselubungi dalam opus alienum Dei, dan terjadi bersamaan. Menurut Luther, dalam Teologia Salib, bukan hanya bahwa Allah dikenal melalui penderitaan (apakah itu Kristus atau individu), tetapi bahwa Allah membuat dirinya dikenal melalui penderitaan. Luther menjelaskan bahwa proses pembenaran yang dialami seseorang pertama-tama dimulai dari kesadaran pribadi yang disertai pengakuan bahwa dirinya berdosa. Merendahkan diri di hadapan Tuhan merupakan sebuah syarat mutlak bagi pembenaran. Bagi Luther, seseorang harus benar-benar dipermalukan di hadapan Allah sebelum mendapatkan pembenaran. Pentingnya penderitaan, apakah ini dipahami sebagai penderitaan Kristus atau Anfechtung (sebuah serangan rohani kepada orang percaya), adalah bahwa hal itu merupakan alienum opus di mana Tuhan bekerja keluar proprium opus-nya (Hill, 2003). Bagi Luther, salib adalah sebuah wahyu tertinggi (supremme revelation) mengenai siapa sesungguhnya Allah yang disebut sebagai "Tuhan Kita" (Platinga, Thompson, \& Lundberg, 2011). Dalam perspektif ini, penderitaan terlihat sebagai jalan pekerjaan Allah.

Dalam pandangan C.S. Lewis (2009), penderitaan di dalam kekristenan menghasilkan paradoks. Di satu pihak penderitaan dianggap tidak baik tetapi di saat bersamaan penderitaan adalah sebuah kebaikan. Menurut Lewis, penderitaan itu 'pada dirinya' tidak baik. Hal yang baik bagi si penderita dalam pengalaman menyakitkan apapun adalah ketundukannya kepada kehendak Allah, dan bagi orang-orang yang menyaksikannya, munculnya belas kasihan dan tindakan-tindakan kasih yang dihasilkan. Lewis me- nekankan, jika penderitaan merupakan elemen yang sangat diperlukan dalam penebusan, manusia harus mengantisipasi bahwa penderitaan tidak akan berhenti sampai Allah melihat dunia ini apakah sudah ditebus atau tidak mungkin ditebus lebih jauh lagi (Lewis, 2009). Dalam bukunya Problem of Pain, Lewis menulis suatu argumen yang patut direnungkan perihal penderitaan sebagai sebuah paradoks kekristenan.

Jika Allah itu baik, Ia semestinya membuat ciptaan-ciptaan-Nya menikmati kebahagiaan sempurna, dan jika Allah itu Mahakuasa, Ia seharusnya sanggup melakukan apa yang diinginkanNya. Akan tetapi, ciptaan-ciptaan tersebut tidak bahagia. Karena itu, entah Allah tidak memiliki kebaikan atau kuasa atau keduanya. Inilah masalah penderitaan dalam bentuknya yang paling sederhana (Lewis, 2009).

Anggapan Lewis tersebut menegaskan satu hal bahwa manusia di dalam kondisi penderitaan apapun tetap berada di dalam kedaulatan Allah yang penuh kasih.

Piper dan Tyler (2012) melihat perluasan penderitaan sebagai bagian eksistensial dari kedaulatan Allah atas manusia. Apapun sebab timbulnya penderitaan itu, dan dari manapun sumber-sumbernya, kedaulatan Allah berlaku atasnya. Tuhan yang memberi ukuran dan menentukan kualitas sebuah penderitaan yang dialami manusia. Kedaulatan Allah bukan sekedar bahwa Allah memiliki kuasa dan hak untuk mengatur semua hal, tetapi bahwa Ia memang mengatur segala hal, demi kebijaksanaan dan maksud-Nya yang kudus (Piper \& Taylor, 2012). Piper dan Taylor merumuskan sepuluh bentuk kedaulatan Allah: 1) Allah berdaulat atas pemerintahan iblis atas dunia yang didelegasikan; 2) Allah berdaulat atas malaikat-malaikat Iblis (setan-setan dan roh-roh jahat); 3) Allah berdaulat atas tangan Iblis dalam penganiayaan; 4) Allah berkuasa atas kuasa Iblis untuk mengambil hidup; 5) Allah berkuasa atas tangan Iblis di dalam bencana alam; 6) Allah berkuasa atas kuasa Iblis mendatangkan penyakit; 7) Allah berkuasa atas penggunaan binatang dan tumbuh-tumbuhan oleh Iblis; 8) Allah berkuasa atas godaan Iblis untuk berbuat dosa; 9) Allah berkuasa atas kuasa Iblis untuk 
pembutaan pikiran; dan 10) Allah berkuasa atas jerat rohani Iblis (Piper \& Taylor, 2012). Aspek-aspek kedaulatan Allah tersebut adalah hasil identifikasi Piper dan Taylor untuk memberi jawaban atas pertanyaan manakah yang lebih berkuasa ketika manusia berada di dalam penderitaan. Tentu saja, seluruh faktor itu tidak lebih berkuasa dari Allah. Menurut Piper dan Taylor sekalipun manusia menganggap bahwa penderitaan dan kejahatan sebagai suatu perkara yang hebat, keduanya tidak dapat menggantikan posisi Allah sebagai yang terhebat (Piper \& Taylor, 2012). Kedaulatan bukan dan tidak berada di tangan setan atau Iblis melainkan tetap di tangan Allah. Dengan kata lain seluruh pengalaman penderitaan itu tetap berada di dalam kontrol-Nya.

Pendapat para teolog yang telah diuraikan di atas, sekalipun beranjak dari titik tolak yang tidak sama, seluruhnya mengarah pada satu titik pengertian. Penderitaan adalah cara Allah menyatakan diri kepada manusia ciptaan-Nya. Sebaliknya, manusia sebagai ciptaan di dalam penderitaan dibawa untuk memahami Allah dan tetap meletakkan iman percaya kepada-Nya. Penderitaan berlangsung di dalam kedaulatan Allah dan manusia tidak memiliki pilihan kecuali memposisikan diri sebagai objek kedaulatan itu. Refleksi iman menjadi hasil yang menguatkan dan membangkitkan harapan.

\section{Konstruk Teologi Penderitaan}

Sebuah Teologi Penderitaan merujuk pada dua hal berikut ini. Pertama, penderitaan yang melekat orang Kristen sebagai sebuah konsekuensi Salib dan dengan demikian, hasil dari penderitaan itu adalah kekayaan Sorgawi pada masa kekekalan. Pada pengertian ini, definisi merujuk pada panggilan untuk ikut menderita (refleksi iman) selama berada di dunia supaya kelak mendapatkan kebahagiaan dan kekayaan sorgawi. Dalam pengertian ini maka manusia memutuskan untuk membangun sebuah gaya hidup menderita yang secara ekstrim dipraktekkan dengan usaha mengasingkan diri dari semua kesenangan dunia, dan segala kemewahannya, dengan sengaja me- milih miskin dan bahkan yang lebih ekstrim lagi munculnya aliran masokhisme, sebuah tindakan menyakiti diri sendiri sebagai bentuk solidaritas kepada Kristus yang telah menderita di atas kayu Salib untuk manusia (Levinson, 2020). Bentuk lain dari paham ini dalam praktik hidup sehari-hari adalah dengan membangun gaya hidup yang sangat sederhana di tengah modernitas. Ini semua adalah sebuah pilihan.

Kedua, istilah teknis teologis yang merujuk pada konsep penderitaan yang dikembangkan dari sejumlah penderitaan manusia selama menjalani hidup di bumi dan melaluinya, manusia mendapat pencerahan akan hubungannya dengan Allah, dapat mengerti siapa dirinya dan melakukan satu usaha untuk membangun pengertian akan penderitaan yang dialami, misalnya: dari mana sumbernya, bagaimana mengatasinya, sikap yang benar di dalam menghadapinya, dimana Allah berada saat penderitaan berlangsung, dan sebagainya. Dalam pengertian kedua, penderitaan lahir dari sebuah kejadian di luar diri manusia yang membawa dampak secara internal, bisa secara baik tetapi pada umumnya buruk. Pada pengertian ini, manusia mencoba membangun konsep teologi sebagai sebuah tanggapan atas situasi yang dialaminya dan mencoba mereposisi hubungannya dengan Tuhan sebagai yang berdaulat atas kehidupan.

Konsep penderitaan sebagai refleksi iman menempatkan manusia yang dengan sengaja memilih menderita sebagai refleksi imannya dan menjauhi berbagai kesenangan duniawi. Isolasi, membiara (asketisme) (Fergusson, Wright, \& Packer, 1988), kemiskinan dan menyiksa diri adalah bagian dari definisi pertama. Penderitaan dianggap sebagai kebahagiaan karena merupakan bagian dari iman. Dalam pemahaman ini, manusia berharap bahwa jalan penderitaan yang ditempuh di dunia pada akhirnya berbuah kebahagiaan di kekekalan. Juga dipahami bahwa penderitaan adalah bentuk solidaritas manusia atas penderitaan Allah. Karena Kristus menderita, maka manusia perlu memperlihatkan dalam kehidupannya sikap ikut menderita, agar dapat lebih da- 
lam memaknai makna kedatangan Kristus di dunia yang memang sarat dengan penderitaan. Dalam konsep ini, penderitaan bukanlah "penderitaan" tetapi panggilan untuk ikut menderita.

Penegasan mengenai panggilan untuk ikut menderita adalah hal alami di dalam terminologi kristiani. Dengan tegas Yesus berkata, "Setiap orang yang mau mengikut Aku, ia harus menyangkal dirinya, memikul salibnya setiap hari dan mengikut Aku" (Luk. 9:23). Hal itu berarti penderitaan apapun yang Tuhan ijinkan terjadi di dalam hidup orang percaya, harus dibingkai dan dimengerti dan dihadapi di dalam bingkai teologis. Banyak faktor penyebab penderitaan yang lahir dalam konteks bermasyarakat seperti masalah hidup, faktor-faktor politik, perang, intimidasi, aniaya, gesekan sosial lainnya, bencana alam, virus, wabah yang kesemuanya itu menjadi penyebab penderitaan fisik dan jiwa manusia. Teologi Penderitaan menjadi tanggap teologis atas konteks penderitaan manusia. Tanggap teologis ini berpijak pada penerimaan penderitaan sebagai sebuah panggilan salib di dalam kehidupan. Oleh karena itu, penderitaan sebagai realisasi salib yan harus dipikul, bukanlah sesuatu yang perlu dinegosiasikan untuk dihindari. Tetapi perlu mengalami penguatan dalam perspektif iman.

Sebetulnya, kedua konsep di atas memiliki dampak yang sama di dalam kehidupan manusia dan umumnya memberi pengaruh pada cara berpikir dan cara bertindak ketika manusia mengalami dan atau berada di dalam penderitaan. Perbedaan tersebut diungkap oleh Dietrich Bonhoeffer, seorang teolog Jerman yang menjadi salah seorang tokoh Ortodoksi Baru. Teolog ini memiliki pengalaman nyata bersinggungan dengan penderitaan karena pernah dipenjara oleh Nazi. Surat-suratnya dari penjara mengungkap pokok-pokok pemikiran teologisnya tentang derita. Salah satunya adalah ketika menulis risalah "Allah Yang Kami Miliki adalah Allah yang Menderita" pada tahun 1944. Menurut Bonhoeffer, ada dua jenis penderitaan yakni "penderitaan umum" dan "penderitaan Kristen." Penderitaan umum mencakup semua penderitaan, penyakit, sakit dan kematian yang misterius sebagai bagian alami dari kehidupan manusia. Jenis penderitaan ini tidak boleh dikaitkan dengan kehendak Allah tetapi terjadi karena dosa dan kejahatan manusia sebagai sebab akibat kejatuhan di Eden. Sedangkan penderitaan Kristen, adalah jenis penderitaan tertentu yang dialami orang Kristen dalam tiga fitur utama: pertama, secara sukarela; kedua, karena menanggung beban orang lain; dan, ketiga, hal itu dilakukan demi Kristus (Godsey, n.d.; Hill, 2003). Dapat disimpulkan bahwa penderitaan yang hadir di dalam kehidupan manusia tidak pernah berlangsung begitu saja tanpa tujuan. Benang merah yang menghubungkan semua pendekatan dari berbagai sudut pandang sebagaimana didiskusikan di atas adalah pentingnya kesadaran akan Allah di kalangan orangorang yang sedang mengalami penderitaan (Stevanus, 2019). Sebagaimana penderitaan Ayub di dalam Alkitab, kekuatan dan kegetarannya terjdi karena kesadaran tersebut.

\section{KESIMPULAN}

Diskusi di atas mengantar pada kesimpulan bahwa konstruk Teologi Penderitaan selalu menghadirkan dialektika antara penderitaan Allah di satu sisi, dan penderitaan manusia di sisi lain. Manusia dapat melihat penderitaannya di dalam penderitaan Allah dan Allah adalah Tuhan yang (ikut) menderita untuk kepentingan manusia. Dalam konteks ini manusia harus mengerti, seberat apapun dan karena faktor apapun, penderitaan yang dialaminya, Allah tidak pernah membiarkan manusia menderita sendirian. Penderitaan secara mutlak berlangsung di dalam kedaulatan Tuhan. Manusia menjadi objek kedaulatan itu tetapi pada saat yang sama menjadi subjek aktif untuk membangun respon iman melalui pengharapan. Surat Rasul Paulus kepada orang-orang Ibrani dengan jelas memberitahukan maksud dan tujuan setiap penderitaan itu, bahwa "karena Tuhan menghajar orang yang dikasihi-Nya, dan Ia menyesah orang yang diakui-Nya sebagai anak" (Ibr. 12:6). Sebuah Teologi Penderitaan adalah teologi yang memposisikan ma- 
nusia untuk menyadari dirinya bukan sebagai objek kemarahan, tetapi sebagai objek kasih Allah.

\section{Kontribusi Penelitian}

Teologi Penderitaan adalah salah satu jalan untuk memahami Allah dengan cara yang ekstrim karena penderitaan cenderung dijauhi oleh orang Kristen. Oleh sebab itu, penelitian ini berkontribusi penuh dalam mengembangkan kajian ilmu teologi penderitaan, yang secara khusus mengembangkan konstruksi teologis keterkaitan Allah-Manusia-Penderitaan. Hasil-hasilnya juga dapat dipergunakan untuk pelayanan

\section{DAFTAR RUJUKAN}

Ahuja, A. S., Reddy, V. P., \& Marques, O. (2020). Artificial intelligence and COVID-19: A multidisciplinary approach. Integrative Medicine Research, 9(3), 100434. https://doi.org/10.1016/j.imr.2020.100434

Andreas A. Yewangoe. (2005). Teologi Bencana.

Boonyakiat, S. (2008). Suffering. In W. A. Dyrness \& V.-M. Karkkainen (Eds.), Global Dictionary of Theology (p. 857). Nottingham: Inter-Varsity Press.

Cipriani, G., \& Fiorino, M. Di. (2020). Access to Care for Dementia Patients Suffering From COVID19. The American Journal of Geriatric Psychiatry, 28(7), 796-797. https://doi.org/10.1016/j.jagp.2020.04.009

Fergusson, S. B., Wright, D. F., \& Packer, J. (1988). New Dictionary of the Theology. Downer s Grove, Illionis: IVP Academic.

Fromm, E. (2019). Revolusi pengharapan [The revolution of hope] (2nd ed.; J. Pieris, Ed.). Bogor: Pelangi Cendekia.

Gilbert, M., Johnson, A. R., \& Lewis, P. W. (Eds.). (2018). Missiological Research. Pasadena, CA: William Carey Publishing.

Godsey, J. D. (n.d.). Dietrich Bonhoeffer On Suffering.

Hill, J. (2003). The History of Christian Thought. England: Lion. pastoral di dalam membimbing orang-orang yang menderita agar mengalami kemerdekaan.

\section{Rekomendasi Penelitian Lanjutan}

Penelitian kuantitatif dapat dilanjutkan untuk mengungkap respon orang Kristen di dalam penderitaan. Pendekatan fenomenologis dapat juga dipergunakan untuk mempelajari bagaimana orang-orang yang telah mengalami tragedi bertahan di dalam penderitaan dan mengalami kemerdekaan di dalam kehidupan rohaninya.

Jamal, T., \& Budke, C. (2020). Tourism in a world with pandemics: local-global responsibility and action. Journal of Tourism Futures, 6(2), 181188. https://doi.org/10.1108/JTF-02-2020-0014 Keener, C. S. (2014). The IVP Bible background commentary - New Testament (2nd ed.). Downer s Grove, Illionis: IVP Academic.

Kurniadi, B. W. (2015). Inspirasi Kisah Ayub bagi Seorang Katolik dalam Menghadapi Penderitaan. Melintas, 31(1), 47. https://doi.org/10.26593/mel.v31i1.1455.47-62

Levinson, N. A. (2020). Masochism. In Female Psychology: An Annotated Psychoanalytic Bibliography (pp. 471-493). https://doi.org/10.4324/9781003070306-24

Lewis, C. S. (2009). The Problem of Pain. bandung: Pionir Jaya.

Lucchetti, G., Góes, L. G., Amaral, S. G., Ganadjian, G. T., Andrade, I., Almeida, P. O. de A., ... Manso, M. E. G. (2020). Spirituality, religiosity and the mental health consequences of social isolation during Covid-19 pandemic. International Journal of Social Psychiatry, 002076402097099.

https://doi.org/10.1177/0020764020970996

McKim, D. K. (2014). The Westminster Dictionary of Theological Terms (2nd ed.). Louisville, Kentucky: Westminster John Knox Press. 
Migliore, D. L. (1975). The Crucified God: The Cross of Christ as the Foundation and Criticism of Christian Theology. Theology Today, 32(1), 98106. https://doi.org/10.1177/004057367503200115

Moltmann, J. (1975). The Experiment Hope (D. Meeks, Ed.). London: SCM Press.

Moltmann, Jür. (1974). The Crucified God. Theology Today, 31(1), 6-18. https://doi.org/10.1177/004057367403100102

Mostert, C. (2013). Moltmann's Crucified God. Journal of Reformed Theology, 7(2), 160-180. https://doi.org/10.1163/15697312-12341293

Piper, J., \& Taylor, J. (2012). Penderitaan dan Kedaulatan Allah. Surabaya: Penerbit Momentum.

Platinga, R. J., Thompson, T. R., \& Lundberg, M. D. (2011). An Introduction to Christian Theology. United Kingdom: Cambridge University Press.

Radbruch, L., Knaul, F. M., de Lima, L., de Joncheere, C., \& Bhadelia, A. (2020). The key role of palliative care in response to the COVID19 tsunami of suffering. The Lancet, 395(10235), 1467-1469. https://doi.org/10.1016/S0140-6736(20)309648

Robert, R., Kentish-Barnes, N., Boyer, A., Laurent, A., Azoulay, E., \& Reignier, J. (2020). Ethical dilemmas due to the Covid-19 pandemic. Annals of Intensive Care, 10(1), 84. https://doi.org/10.1186/s13613-020-00702-7

Sparshott, F. E. (2017). Credo ut Intelligam. https://doi.org/10.2307/j.ctt1w6t9ff.8

Stevanus, K. (2019). Kesadaran Akan Allah Melalui Penderitaan Berdasarkan Ayub 1-2. DUNAMIS: Jurnal Teologi Dan Pendidikan Kristiani, 3(2), 111. https://doi.org/10.30648/dun.v3i2.182

Wang, Y. (2021). Government policies, national culture and social distancing during the first wave of the COVID-19 pandemic: International evidence. Safety Science, 135, 105138. https://doi.org/10.1016/j.ssci.2020.105138

Weinandy, T. G. (2003). Does God Suffer? Pro Ecclesia: A Journal of Catholic and Evangelical Theology, 12(1), 108-110. https://doi.org/10.1177/106385120301200108

Wicaksono, A., \& Anggono, D. (2019). Yesus, Hamba Allah Yang Menderita. FIDEI: Jurnal Teologi Sistematika Dan Praktika, 2(1), 145161. https://doi.org/10.34081/fidei.v2i1.44

Zaluchu, S. (2017). Penderitaan Kristus Sebagai Wujud Solidaritas Allah Kepada Manusia [The Suffering of Christ as Solidarity between God and Man]. DUNAMIS: Jurnal Penelitian Teologi Dan Pendidikan Kristiani [DUNAMIS: Journal of Theology Research and Christian Education], 2(1), 61 https://doi.org/10.30648/dun.v2i1.129 